\title{
Occupational Stress among Nurses of tertiary Care Hospitals in Tiruvarur
}

\author{
R.Sasikala ${ }^{1}$, Dr.G.Ramu ${ }^{2}$
}

${ }^{1}$ M.Com.,M.Phil.,Research Scholar,Department Of Commerce,Thiru.Vi.Ka.Govt. Arts College, Tiruvarur.

${ }^{2}$ M.Com.,MBA.,M.Phil.,Ph.D.,Assistant Professor And Research Supervisor,P.G.And Research Department Of Commerce, Thiru.Vi.Ka.Govt. Arts College, Tiruvarur.

\begin{abstract}
:
Stress is physiological and psychological response towards any occurrences. It is very much vitalto learn about occupational stress because as it deters health and decreases the quality of work of nurses. The main objective was to determine prevalence, intensity and causes of occupational stress among nurses.Hospital based analytical cross-sectional study was conducted from January to November 2017 at two tertiary care teaching hospitals of Tiruvarur. The study was carried out on 265 registered nurses, having valid license by Tamil Nadu Nursing Council. Convenient non-probability method was used to access subjects. After taking consent, semi-structured and pre-tested occupational stress questionnaire was used to obtain the data. The study results revealed that majority of nurses 125 (47.2\%) were between 25 to 30 years of age.Maximum ratio of nurses were female $160(60.4 \%)$ and out of them 148(55.8\%) were married. Two hundredand one (75.8\%) were diploma holders in nursing, while only 2(0.8\%) had done their master in nursing. Thestudy participants reported to suffer with job related stress; mild stress $2.0 \%$, moderate stress $36.5 \%$ and severe $61.5 \%$.
\end{abstract}

Keywords: Nurses, stress, occupational stress, tertiary care hospitals, Tiruvarur.

\section{Introduction}

Nursing profession is recognized as a gratifying and rewarding profession while it is also identified as avery stressful profession. Severe and moderate levelof occupational stress decreases nurses overall health including mentally, physically and socially.Perpetual workload, lack of autonomy, lack of status,lack of resources, conflicts, reduced pay scale, and lack of motivation are key factors responsible for developing occupational stress among nurses. It is documented that nurses look after many patients and fulfill several tasks as well. Thus, nurses are overburdened and an undue victims of job stress. It has been confirmed by recent research that one in five nurses wish to quit their job and $40 \%$ nurses experience considerable burnout. Consequently, burnout is the leading source of causing job stress.

It has been affirmed by current research that Occupational stress is the significant problem amongnurses in several parts of the world. Further, recentresearch suggests that several work-related stressors are associated with nursing including poor social support, lake of knowledge as well as noise
pollution.It is affirmed by another recent research that occupational stress is very dangerous for nurses andfor the organization. It deters nurse's health both physically and mentally during job. Physically andmentally disturbed nurses feel ill and insecure on the duty, so the elements such as illness, lack of motivation,insecurity can cause stress among nurses at workplace. Occupational stress has significant impact on organizational overall growth. Additionally, organizations whose employees are stressed may turn out unsuccessful, less productive and less dynamic. Documentary evidence by research shows that role boundary and role insufficiency are leading indicators for occupational stress among nurses. Research study conducted in Delhi, India shows that Indian nurses are extremely overburdened and the prevalence of occupational stress among Indian nurses are very high.

\section{Materials \& Methods}

The study design is analytical cross-sectional. This study was performed at dual tertiary care medical institutions of Tiruvarur. The study subjects were both male and female registered nurses with full 
time Job, however serving either in Regular or contract basis with two years working experience. Further, valid license holders by Tamil Nadu Nursing Council were approached in this study. Two years work experience was included because nurses can understand the working environment and perceive the stressors at work place.

Those nurses who refused to give the consent were excluded. Convenient nonprobability method was used to access subjects. The study duration was 11 months from between January and November 2017. Calculated sample size was 265 subjects including both genders. The participation of subjects was voluntary. The participant who reported severe stress was referred to psychiatrist for counseling.

Subjects were recruited by convenient nonprobability method and prior permission of head nurses. Subjects were inquired and helped in finalizing semi-structured pro-forma comprising socio-demographic info and semi- structured occupational stress questionnaire. The participants were approached for data collection in the morning shift, evening shift and night shift duty. Only Registered nurses of Civil hospital were approached on their working place on Monday and the same Registered nurses of Tiruvarur hospital were approached on their working place on Saturday.A validated "Occupational stress questionnaire"developed by Bhatia N, (2010)1 was adopted after modification.

Pilot study was conducted on $10 \%$ of total sample size.The subjects included in pilot study were excluded from the original study. The study was piloted at Tiruvarur Hospital. A minor vagueness on some questions was noticed and rectified.The reliability of the questionnaire was checked by Chronbech's Alpha test. The result of this test showed that the questionnaire is $91.4 \%$ is reliable. SPSS version 21.0 was used to enter and analyses of the data.

Chi-squire test was used for relationship of the differences among sex, age, matrimonial status, period's liability and amount of work alongside the conclusion variable. Significance level was deliberated at a $\mathrm{p}$ value of 0.05 .

All procedures followed were in accordance with the ethical standards of the responsible committee on human experimentation (institutional and national) and with the Helsinki Declaration of 1975, as revised in 2008. Informed consent was obtained from all patientsfor being included in the study.

\section{Results}

A total of 265 nurses contributed to the study, 125 (47.2\%) nurses were between age 25 to 30 years. Out of total, 160(60.4\%) major chunk was female and $148(55.8 \%)$ were married. Majority of nurses 201(75.85\%) completed diploma in nursing, 62(23.40\%) were BSN Post RN graduated, while only $2(0.8 \%)$ had done their master in nursing.

$26(9.8 \%)$ nurses were serving in the capacity of head nurse and $239(90 \%)$ as staff nurse.Out of the total 265 nurses, 168 (63.4\%) nurses were working in morning shift and 32(12.1\%) are working double job. Majority $218(82.3 \%)$ were working asregular employee.

Out of total, most of the nurses110(41.5\%) live 10 to $20 \mathrm{~km}$ from their work place.The majority $109(41.1 \%)$ nurses had been working for1 to 5 years at the time of study. Approximately onethird 86 $(32.5 \%)$ nurses had been earning above 44,000PKR. In Table 2, the stressors are directly related to nursesJobs. Majority 195 (73.6\%) of the nurses strongly agree/ agree that they were required to travel a lot for their job. Only three nurses strongly disagreed that their job required high skill. Approximately $60 \%$ of nurses said that their job does not allow freedom to decide how they work. 91 nurses disagreed with the statement there was much pressure of work by doctor. More than half $152(57.4 \%)$ of nurses agreed that their job is very hectic. Majority 196 (74\%) of nurses claimed that theyhave to attend many patients. Only $14 \%$ nurses strongly agreed to the fact their supervisor/senior nurse are not cooperative and unlike 69 (26.0\%) told that there is pressure to learn new things in their job. Out of total nurses, 172(64.9\%) nurses stated that there is insufficient sleep and frequent call in their job.127 (47.9\%) had stress due to high rates of deaths among patients in their hospital. Moreover, $27.5 \%$ (75) participants agreed or strongly agreed to report sexual harassment.

Table 1 Demographic information of study participants

\begin{tabular}{|l|l|l|}
\hline Information & $\mathbf{n}$ & \% \\
\hline Age (Years) & 125 & 47.2 \\
\hline $25-30$ & 42 & 15.8 \\
\hline $31-35$ & 46 & 17.4 \\
\hline $36-40$ & 52 & 19.6 \\
\hline $41 \&$ above & 105 & 39.6 \\
\hline Gender & 160 & 60.4 \\
\hline
\end{tabular}




\begin{tabular}{|l|l|l|}
\hline Male & 114 & 43.0 \\
\hline Female & 148 & 55.8 \\
\hline Marital status & 3 & 1.1 \\
\hline Single & 201 & 75.8 \\
\hline Married & 62 & 23.4 \\
\hline Widow & 2 & 0.8 \\
\hline Qualification & $\mathrm{n}$ & $\%$ \\
\hline Diploma in nursing & 125 & 47.2 \\
\hline BSN post RN & 42 & 15.8 \\
\hline MSN & 46 & 17.4 \\
\hline
\end{tabular}

Table 2 Percentage distribution of various stressors directly related to nurses Jobs

\begin{tabular}{|c|c|c|c|c|c|}
\hline Stressors & $\begin{array}{l}\text { Strongly } \\
\text { stress }\end{array}$ & Agree & 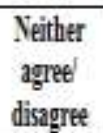 & Disagreet & $\begin{array}{l}\text { Strongly } \\
\text { disagree }\end{array}$ \\
\hline Freyperacy (96) & (\%) & $\begin{array}{l}\mathbb{1} \\
(\%)\end{array}$ & I & $\begin{array}{c}\text { I } \\
\text { (4) }\end{array}$ & $\begin{array}{l}\text { n } \\
(\%)\end{array}$ \\
\hline $\begin{array}{l}\text { you ace requiredto travel a } \\
\text { lot invour job }\end{array}$ & $\begin{array}{c}101 \\
(38.1)\end{array}$ & $\begin{array}{c}94 \\
(35.5)\end{array}$ & $\begin{array}{c}42 \\
(15.8)\end{array}$ & $\begin{array}{c}21 \\
(79)\end{array}$ & $\begin{array}{c}7 \\
(2.6)\end{array}$ \\
\hline $\begin{array}{l}\text { your job requiruligh } \\
\text { level of sill }\end{array}$ & $\begin{array}{l}101 \\
(38.1)\end{array}$ & $\begin{array}{c}115 \\
(43.4)\end{array}$ & $\begin{array}{c}40 \\
(15.1)\end{array}$ & $\begin{array}{c}6 \\
6 \\
(23)\end{array}$ & $\begin{array}{c}3 \\
(1.1)\end{array}$ \\
\hline $\begin{array}{l}\text { your job does notallorr } \\
\text { you fredtonto decide horr } \\
\text { dorou worls }\end{array}$ & $\begin{array}{c}75 \\
(28.3)\end{array}$ & $\begin{array}{c}82 \\
(30.9)\end{array}$ & $\begin{array}{c}67 \\
(25.3)\end{array}$ & $\begin{array}{c}32 \\
(12.1)\end{array}$ & (3.4) \\
\hline $\begin{array}{l}\text { there is muchypessure } \\
\text { by dotor }\end{array}$ & $\begin{array}{c}52 \\
(19.6)\end{array}$ & $\begin{array}{c}66 \\
(249)\end{array}$ & $\begin{array}{c}56 \\
(21.1)\end{array}$ & $\begin{array}{c}75 \\
(28.3)\end{array}$ & $\begin{array}{l}16 \\
(6.0)\end{array}$ \\
\hline your job is veryactic & $\begin{array}{c}54 \\
(20.4)\end{array}$ & $\begin{array}{c}98 \\
(37.0)\end{array}$ & $\begin{array}{c}59 \\
(223)\end{array}$ & $\begin{array}{c}41 \\
(15.5)\end{array}$ & $\begin{array}{c}13 \\
(4.9)\end{array}$ \\
\hline $\begin{array}{l}\text { you have to attendmany } \\
\text { potients }\end{array}$ & $\begin{array}{c}106 \\
(40.0)\end{array}$ & $\begin{array}{c}90 \\
(34.0)\end{array}$ & $\begin{array}{c}39 \\
(14.7)\end{array}$ & $\begin{array}{c}18 \\
(6.8)\end{array}$ & $\begin{array}{c}12 \\
(4.5)\end{array}$ \\
\hline $\begin{array}{l}\text { you are exposed toserval } \\
\text { harassmentby team } \\
\text { members }\end{array}$ & $\begin{array}{c}23 \\
(8.7)\end{array}$ & $\begin{array}{c}50 \\
(18.9)\end{array}$ & $\begin{array}{l}49 \\
(18.5)\end{array}$ & $\begin{array}{c}45 \\
(17.4)\end{array}$ & $\begin{array}{c}97 \\
(36.0)\end{array}$ \\
\hline $\begin{array}{l}\text { your } \\
\text { siperviso secionurse } \\
\text { arenot cooperative }\end{array}$ & $\begin{array}{c}37 \\
(14.0)\end{array}$ & $\begin{array}{c}73 \\
(27.5)\end{array}$ & $\begin{array}{c}71 \\
(26.8)\end{array}$ & $\begin{array}{l}57 \\
(21.5)\end{array}$ & $\begin{array}{c}27 \\
(10.2)\end{array}$ \\
\hline $\begin{array}{l}\text { there is pressureto learl } \\
\text { new flings }\end{array}$ & $\begin{array}{c}69 \\
(26.0)\end{array}$ & $\begin{array}{c}87 \\
(32.8)\end{array}$ & $\begin{array}{c}73 \\
(27.5)\end{array}$ & $\begin{array}{c}30 \\
(11.3)\end{array}$ & $\begin{array}{c}6 \\
(2.3)\end{array}$ \\
\hline $\begin{array}{l}\text { there is insuficientslesp } \\
\text { abiffequent call }\end{array}$ & $\begin{array}{c}92 \\
(34.7)\end{array}$ & $\begin{array}{c}80 \\
(30.2)\end{array}$ & $\begin{array}{c}52 \\
(19.6)\end{array}$ & $\begin{array}{c}37 \\
(14.0)\end{array}$ & $\begin{array}{c}4 \\
(1.5)\end{array}$ \\
\hline $\begin{array}{l}\text { there is stress duato bigh } \\
\text { rates ofdeatis anoug } \\
\text { petients }\end{array}$ & $\begin{array}{c}48 \\
(18.1)\end{array}$ & $\begin{array}{c}79 \\
(29.8)\end{array}$ & $\begin{array}{c}61 \\
(23.0)\end{array}$ & $\begin{array}{c}62 \\
(23.4)\end{array}$ & $\begin{array}{l}15 \\
(5.7)\end{array}$ \\
\hline
\end{tabular}

\section{Discussion}

Stress is a multidimensional phenomenon and many studies signify that medical professionals such as nurses have multiple types of stress in their occupational span. It has been recognized that nurses are backbone of any health care system.

Yet at the same time they remain under stress due totheir job responsibilities in addition to other professional commitments. Factors such as workload, procedural injustice, role ambiguity, conflicts in family or at workplace and environment affect the job performance15. However, there is a limited researchon job stress in relation to health in developing countries.

In a few studies, the stress of job on nurses is focused, like in a study carried out in India1, the average age of nurses was 32.5 years. (Ranging from 19 years -41 years). In another study17 the subjects stayed up to 20- 50 years of age. The aforementioned study concurring results were almost alike the Indian study due to the fact that the age group of nursing participants in this study was also 25 to 50 years. Rendering to the present study, stress turned more severe as older subjects rose, though it was not statistically significant as such. $(\mathrm{P}=0.06)$.

In further studies, the mean of working-experience ofthe nurses was 7.8 years and 16 years $(1$, and 23 respectively). In another study18 the work experience of nurses was from 1 year to 16 and above years. In a study it was reported that majority $(52.6 \%)$ of the nurses had up to 10 years of experience. In this study also majority $(66.0 \%)$ have work experience up to 10 years. The overall working experience ranged from 1 year to 30 years.

Regarding age and marital status of nurses, in a study16 majority $76.7 \%$ were females and \%). Similarly, in another study1 major number of (80.4\%) participant was married.

In the current study, subjects were also comparable tothose as $60.4 \%$ of the participants were females and $39.6 \%$ were males and $55.8 \%$ of them were married. While gender and marital standing was not establishing any significance in terms of a stressor on professional health care providers. $(\mathrm{P}=0.98 \&$ $\mathrm{P}=0.79$ respectively.) Regarding qualifications of the nurses, according to a study 19 majority $(60.9 \%)$ were graduates. In a study19 it was calculated that in the United States only $12 \%$ nurses have a master degree. In our study also, majority of the participants were either simple diploma holder in nursing $(75.8 \%)$ or only $23.4 \%$ were graduate and only $0.8 \%$ had master degree.

In a study, the nurses who claimed their jobs free from stress were having mean duration of job 5.64 years whereas nurses whose mean years of working was 10.14 find their jobs extremely stressful. The same study resulted that $87.4 \%$ of the participants found their job stressful but $32.2 \%$ found it extremely stressing. In another study 19 no nurse claimed to be stress free unlike $46.7 \%$ showed mild 
stress, followed by $40 \%$ moderate and only $13.3 \%$ severe stress. In astudy 20 the mean of the stress was $30.39 \pm 7.27$. Inanother study 21 the results showed significant correlation between nurses' performance and components of job $(\mathrm{r}=0.53)$. It was identified that no significant correlation between stress level and some demographic information such as quality of life or occupational stress and factors like position, shift, ward, experiences, time off, overtime hours, interest in desertion and education occurred. In contrast, another study22 showed significant relationships to job satisfaction $(\mathrm{p}<0.01)$ : job stress (-0.568), and psychological empowerment (0.482). Inthis study the job related stress was found mild in only $2.0 \%$ cases, on the other hand, it was found moderate in $36.5 \%$ participants jumping to severe in $61.5 \%$ participants.

\section{Limitations}

This study was carried out in two public sector tertiary care hospitals of Tiruvarur so results cannot be generalized for all population. The participants in the study belonged to urban setting of hospitals. Thus; the results could not be applied to nurses of the hospitals in rural area settings. The study was conducted in public sector hospitals, so it can figure level of stress out among nurses working in private sector.

\section{Conclusion}

The current research paper gave an awareness of problem related to occupational stress among health care givers (Nurses) at tertiary level in the hospitals. The study outcomes established conclusively that an overwhelming portion of nurses' population setting had reported moderate and occupational stress level that may deter their professional and social accountabilities. Ultimately, it is suggested that occupational stress ought to be reduced by implementing suitable management and radical changes in service environment atmosphere. These results may benefit nurses to improve mental health as well as to cope with stress level that empower nurses to ensure quality patient care.

\section{Recommendations}

It is recommended that Largescale follow up study may be conducted that will identify factors causing stress in nursing group. Government should incorporate stress reduction programs in national health policy. Reasonable salary packages should be given.Continuous nursing educational (CNE) sessions shouldbe conducted to enhance nursing skills. Overcome nurses-shortage by hiring more nurses.

\section{References}

[1] Bhatia N, Kishore J, Anand T, Jiloha RC. Occupationalstress amongst nurses from two tertiary care hospitals in Delhi. Au Med J 2010; 3:731-8.

[2] Demerouti E, Bakker AB, Nachreiner F, Schaufeli WB. A model of burnout and life satisfaction amongst nurses.J Adv Nursing 2000; 32:454-64.

[3] Stacciarini JM, Troccoli BT. Occupational stress and constructive thinking: health and job satisfaction. J Adv Nursing 2004; 46:480-7.

[4] Jaafarpour M, Khani A. Evaluation of the nurses' job satisfaction, and its association with their moral sensitivities and well-being. J Clin Diagnostic Res 2012; 6:1761.

[5] Murphy F. Stress among nephrology nurses in NorthernIreland. Nephrol Nursing J 2004; 31:423. 